\title{
Lost in the 'Buzzword': Pre-service Student Teachers' Perceptions of Critical Thinking Instructions
}

\author{
S Imelwaty ${ }^{1}, \mathrm{Y} \mathrm{Merina}^{2}, \mathrm{M}$ Theresia $^{3}$, Armet $^{4}$ \\ $1,2,3,4$ STKIP PGRI Sumatera Barat, Indonesia \\ \{imelwaty05@stkip-pgri-sumbar.ac.id ${ }^{1}$,yolam3@gmail.com², bukittinggi511@gmail.com ${ }^{3}$, \\ armetpgri@gmail.com $\left.{ }^{4}\right\}$
}

\begin{abstract}
Critical thinking (henceforth CT) has become one of the buzzwords among modern society as one of the human survival skills. Therefore, critical thinking instruction (henceforth CTI) should be inculcated in English language teaching as they may increase the English learners' competence and performance. However, little is known regarding the teachers of English perceptions regarding CTI particularly within the pre-service student teachers' instructions in the Indonesian context. In terms of perception, it may influence teachers' behaviors in the classrooms. To this end, this study was conducted to identify the patterns of pre-service student teachers' perceptions of CTI in their teaching practices. A small cohort of pre-service student teachers, who had just finished their teaching practices at schools around West Sumatra province, Indonesia, became the participants of this study. The data were collected using a "perceptions of critical thinking instruction" questionnaire that the list of its questions were proposed by [3] and then revised and added by [14]. The results showed that the pre-service student teachers, perceived CT is essential for students' development in learning. However, in their roles in CTI, their responses were varying. It is suggested that English language teaching program should enhance the concept of CT and the principles of CTI so that pre-service student teachers' knowledge of CT and how to inculcate CTI in their classroom practices could be developed.
\end{abstract}

Keywords: Critical Thinking, Perception, Pre-service Student Teachers

\section{INTRODUCTION}

It has been known that in a learning process, especially in English language teaching and learning, the teachers duty do not only implement learning activities to achieve the objectives of learning at the level of knowing, understanding and using, but also able to grow the process of critical thinking- actively conceptualizing, applying, analyzing, synthesizing, questioning, and/ or evaluating. Every teacher who teaches in the classroom needs to realize it. They should provide the students with significant information or activities that automatically guide them to think critically. In reality, the phenomena are quite the opposite with the critical thinking theory which requires students to think effectively to solve the problem and to decide, [5]. As the effect, teachers often meet with the passive students during the learning process. They tend 
to receive whatever the teachers given without trying to build their critical thinking by arguing, criticizing and analyzing the materials.

According to [5] that CT should be enhanced by the teachers through teaching materials. In this approach, it needs the teachers' attentions and efforts in order to make the students fully engage in the learning process. The teachers should implement their teaching in considering the level of students' acceptance. It is clearly can be seen from the students' feedback through the questions given by the teachers. Moreover, teaching techniques should also be used to stimulate the students for achieving the set of learning objectives. It becomes an alternative way to make the students involve in any activities so that they obtain the knowledge and the skills by their own efforts, while the teachers just facilitate them to gain the learning objectives. Regarding to the statement above, for all the teachers, they are strongly suggested to make the students have willingness to learn and develop their thinking skill not only to be able to answer all the questions orally or in written test. [6] in [1] claim that all teachers should ensure that classroom assessment and training focus on the elements of higher order thinking skills (HOTS) and not only the answer all the questions. It is widely known that asking a question is proposed only to explore what the students have known.It is not enough by using the classical view to check the students' achievement by proposing some questions. However, the teachers should ensure the students using their power, knowledge and materials to think, analyze and others. This situation can train them become decision-maker and autonomous learners because they are internally motivated to seek out new learning method, insight and skills.

Critical thinking is not a novel term for the teachers and practices. However it can be defined either in a broad sense and narrow one. In the broad sense, critical thinking is a way of thinking using cognitive skills, can be rooted from Bloom taxonomy or other taxonomy, involving deep analysis, synthesis and reflection, evaluation, to get as close as possible to the truth to foster understanding, decision-making and guide action [10]. In this situation, a student who used to stop at the level of understanding the material began to analyze, synthesize and ultimately able to evaluate and even judge. The first is analyzing which is a skill to describe a concept into a detailed form. This is the same as explaining the problem systematically with the logical steps in the thinking process to arrive the conclusion. For example, in language learning the students are not only able to speak in English but also they can analyze the discourse and semantics. The second is synthesizing. It is highly believed that synthesizing skills is the skill of incorporating parts into a new form or arrangement. In this case, students are required to integrate all the information obtained to create new ideas. The last is evaluating and judging. At this domain, students are required that he or she is able to synergize other cognitive aspects in assessing a fact or concept. As a result, the purpose of teaching and learning process to elaborate the students are able to think critically can be gained maximally if the teacher can provide their teaching and learning activities which lead to the critical thinking development.

In a narrow sense, it is restricted that critical thinking is a type of reasonable, reflective thinking that is aimed at deciding what to believe or what to do and they need something to think critically about [2] [8]. The problem is that learning process does not represent the critical thinking domains. In general cases, they students may do the tasks or assignment just to fulfill the teachers' requirements. Some students may tend to cheat during the learning or they think that learning process is unimportant for them so that they avoid learning. Ideally, in critical thinking concept, there are several efforts that can be done to develop this critical thinking activity based on the explanations of previous experts. First, the students clarify the statement received, and seek for additional information. Furthermore, they try to analyze the 
information and create it into a new logical idea. Finally, the student is asked to give an explanation and to evaluate his or her statement.

Critical thinking is very crucial in teaching and learning especially for the students' achievement but also to their future demand. According to [11] critical thinking skills play significant roles not only in learners' academic achievements but also in their dynamic life of workforce after graduation. It clearly indicates that the development of critical thinking skills related to student life is very important. This awareness needs to be a foothold or foundation for teachers and practitioners in designing lessons. This is the main reason for teachers who should arrange the teaching program based on the concept of critical thinking. In the context of English language teaching, there is little information empirically established regarding the perceptions of the teachers of English and the pre-service student teachers about critical thinking instruction. It is necessary to study those teachers' perceptions about critical thinking and critical thinking instruction. To this end, this study has tried to identify the patterns of the pre-service perception of critical thinking instructions. The results could informed the preparation program which could be given to the pre-service teachers prior to their teaching practices.

\section{RESEARCH METHOD}

To accomplish the purpose of the study, a survey design was employed and qualitative method was used to obtain the response from participants. The study employed a survey design. It is argued that this approach is appropriate for such a study because it's developmental nature. content analysis method was applied in analyzing the data in responses of participants. A number of respondents were the students who were enrolled in English teaching education program at one of the teacher collages in West Sumatra, Indonesia. They were selected using a purposive sampling and the number of students who become respondents were fifty students. List of questions which were proposed by [3] and then revised and added by [16] was used as the instrument for collecting the data. The questions were comprised by Likert-scale and it used scale of strongly agree (5) to strongly disagree (1). the number of question lists in questionnaire were fourteen questions which composed by close questions. The respondents gave their responses by answering the questions on the available online survey.

\section{RESULTS AND DISCUSSION}

To identify the patterns in the pre-service student teachers' perceptions of critical thinking instruction, the questionnaire was distributed online to a cohort of pre-service student teachers at one of the teacher collages in West Sumatra province, Indonesia. They have just finished their teaching practice at the schools around the province. 50 pre-service student teachers out of 105 gave their responses of the online survey. The questionnaire consists of 14 atatements which are categoried two themes i.e. the students development of critical thinking and the preservice students teacher's roles of the critical thinking instructions. The results of the preservice student teachers' perception toward the teacher's roles of critical thinking instructions can be seen in table 1 . 
Table 1. Responses of the pre-service student teachers toward the teachers' roles of critical thinking instruction

\begin{tabular}{|c|c|c|c|c|c|c|}
\hline No & Statements & $\begin{array}{l}\text { Strongly } \\
\text { disagree } \\
\text { (1) }\end{array}$ & $\begin{array}{c}\text { Disagre } \\
\text { e (2) }\end{array}$ & $\begin{array}{l}\text { Neither } \\
\text { agree } \\
\text { and } \\
\text { disagree } \\
\text { (3) } \\
\end{array}$ & $\begin{array}{c}\text { Agree } \\
\text { (4) }\end{array}$ & $\begin{array}{l}\text { Strongly } \\
\text { Agree } \\
\text { (5) }\end{array}$ \\
\hline 1 & $\begin{array}{l}\text { I believe that it is my } \\
\text { responsibility to cultivate } \\
\text { CT in my courses. }\end{array}$ & $0(0 \%)$ & $0(0 \%)$ & $7(14 . \%)$ & $\begin{array}{c}31 \\
(63 . \%)\end{array}$ & $\begin{array}{c}11 \\
(22.4 \%)\end{array}$ \\
\hline 2 & $\begin{array}{l}\text { I am conscious when } \\
\text { students use CT in my } \\
\text { courses. }\end{array}$ & $0(0 \%)$ & $0(0 \%)$ & $5(10 \%)$ & $\begin{array}{c}34 \\
(68 \%)\end{array}$ & $11(22 \%)$ \\
\hline 3 & $\begin{array}{l}\text { I look for specific } \\
\text { evidence of CT by } \\
\text { students in my courses. }\end{array}$ & $0(0 \%)$ & $0(0 \%)$ & $10(20 \%)$ & $\begin{array}{c}32 \\
(64 \%)\end{array}$ & $8(16 \%)$ \\
\hline 4 & $\begin{array}{l}\text { If required, I could } \\
\text { implement CT into my } \\
\text { courses. }\end{array}$ & $0(0 \%)$ & $0(0 \%)$ & $6(12 \%)$ & $\begin{array}{c}34 \\
(68 \%)\end{array}$ & $10(20 \%)$ \\
\hline 5 & $\begin{array}{l}\text { In order for me to fully } \\
\text { implement CT into my } \\
\text { courses I would need } \\
\text { additional support. }\end{array}$ & $0(0 \%)$ & $0(0 \%)$ & $2(4 \%)$ & $\begin{array}{c}26 \\
(52 \%)\end{array}$ & $22(44 \%)$ \\
\hline 6 & $\begin{array}{l}\text { I have the skills necessary } \\
\text { to promote CT by students } \\
\text { in my courses. }\end{array}$ & $0(0 \%)$ & $2(4 \%)$ & $9(18 \%)$ & $\begin{array}{c}31 \\
(62 \%)\end{array}$ & $8(16 \%)$ \\
\hline 7 & $\begin{array}{l}\text { I think that students have } \\
\text { barriers to CT, regardless } \\
\text { of the strategies I use. }\end{array}$ & $2(4 \%)$ & $1(2 \%)$ & $12(24 \%)$ & $\begin{array}{c}30 \\
(60 \%)\end{array}$ & $5(10 \%)$ \\
\hline
\end{tabular}

Based on the data in table 1, it showed that the responses of statement no 5 had the higher percentage in the category of strongly agree. This statement is about additional supports for implementating the critical thinking into the pre-service students teachers' classrooms. This suggested that they eagerly need additional trainings and coachings on how to cunduct the critical thinking instruction. In addition, only statements number 2 and 4 had the highest responses on agreement indicating they support the implementation of CTI in their teaching practices. On the other hand, the statement number 7 stating that had various ranging responses indicating that these the pre-service student teachers percieved a limbo toward their students ability to think critically. Overal, these students teachers percieved that their roles for CTI is crucial and the need of guidance to implement it. 
Table 2. Responses of the pre-servive student teachers toward the students development of critical thinking

\begin{tabular}{|c|c|c|c|c|c|c|}
\hline No & Statements & $\begin{array}{l}\text { Strongl } \\
y \\
\text { disagre } \\
\text { e (1) }\end{array}$ & $\begin{array}{l}\text { Disagre } \\
\text { e (2) }\end{array}$ & $\begin{array}{c}\text { Neither } \\
\text { agree and } \\
\text { disagree (3) }\end{array}$ & $\begin{array}{l}\text { Agree } \\
\text { (4) }\end{array}$ & $\begin{array}{l}\text { Strongl } \\
\text { y Agree } \\
\text { (5) }\end{array}$ \\
\hline 1. & $\begin{array}{l}\text { CT engages students' } \\
\text { higher order thinking } \\
\text { (analysis, synthesis, and } \\
\text { evaluation). }\end{array}$ & $0(0 \%)$ & $0(0 \%)$ & $0(0 \%)$ & $\begin{array}{c}27 \\
(54 \%)\end{array}$ & $\begin{array}{c}23 \\
(46 \%)\end{array}$ \\
\hline 2. & $\begin{array}{l}\text { CT encourages students to } \\
\text { be an active learner. }\end{array}$ & $0(0 \%)$ & $0(0 \%)$ & $0(0 \%)$ & $\begin{array}{c}27 \\
(54 \%)\end{array}$ & $\begin{array}{c}23 \\
(46 \%)\end{array}$ \\
\hline 3. & $\begin{array}{l}\text { CT can be used to archive } \\
\text { better learning outcomes. }\end{array}$ & $0(0 \%)$ & $0(0 \%)$ & $3(6 \%)$ & $\begin{array}{c}21 \\
(42 \%)\end{array}$ & $\begin{array}{c}26 \\
(53 \%)\end{array}$ \\
\hline 4. & $\begin{array}{l}\text { CT should always include } \\
\text { a reflective component. }\end{array}$ & $0(0 \%)$ & $0(0 \%)$ & $7(14 \%)$ & $\begin{array}{c}28 \\
(56 \%)\end{array}$ & $\begin{array}{c}15 \\
(30 \%)\end{array}$ \\
\hline 5. & $\begin{array}{l}\text { CT encourages students to } \\
\text { be an independent thinker. }\end{array}$ & $0(0 \%)$ & $1(2 \%)$ & $0(0 \%)$ & $\begin{array}{c}26 \\
(52 \%)\end{array}$ & $\begin{array}{c}23 \\
(46 \%)\end{array}$ \\
\hline 6. & $\begin{array}{l}\text { CT will allow students a } \\
\text { better understanding of } \\
\text { course topics. }\end{array}$ & $0(0 \%)$ & $1(2 \%)$ & $1(2 \%)$ & $\begin{array}{c}30 \\
(60 \%)\end{array}$ & $\begin{array}{c}18 \\
(36 \%)\end{array}$ \\
\hline 7. & $\begin{array}{l}\text { CT is a method of } \\
\text { thinking which would help } \\
\text { students enjoy the learning } \\
\text { process. }\end{array}$ & $0(0 \%)$ & $\begin{array}{c}3 \\
(6.1 \%)\end{array}$ & $4(8.2 \%)$ & $\begin{array}{c}32 \\
(65 . \%)\end{array}$ & $\begin{array}{c}10 \\
(20 . \%)\end{array}$ \\
\hline
\end{tabular}

The table 2 shows an intent responses either "agree" or "strongly agree" on the student development of CT. The responses of the statement number 3 for strongly agree was $53 \%$ and it was the higest percentage than other statements. It is an evidence showing that the preservice student teachers have positive opinion regarding critical thinking which could enhance better learning outcomes. Futhermore, statement number 7 showed "agree" on critical thinking is a method of thinking which would help students enjoy the learning process. It can be assumed that by using this method, the pre-service students teachers percieved that CT could make their students be active on the learning process. The pre-service student teachers also showed a greater variance in giving responses on either "disagree" or "neither agree and disagree" on the statements concerning the student development of CT. None of them provided responses on the strongly disagree level suggesting that they percieved CT is deeply needed for developing students ability in achieving the learning outcomes.

Almost all of the responses on thoses statements showed that the pre-service student teachers' perception of critical thinking and critical thinking instructions were still on the position of agreeing (level 4). The higher percentage for showing agreeing were available on the statements: I am conscious when students use CT in my courses and If required, I could implement CT into my courses. Both statements focus on the teacher' roles of the critical thinking instruction. These pre-service student teachers'were aware of the idea that it is the teacher's role to implement the critical thinking to their students as it is needed by the students 
in their future life. It is supported by [14] that critical thinking of students will appear if it was needed in a particular situation. Other responses on the statements conserning the roles of the teachers in critical thinking instructions were varying indicating the needs for more exposure on their courses which discuss and explore the teachers roles to develop their students critical thinking.

Regarding the students development of critical thinking, these pre-service student teachers have began to recognize the importance to crtical tinking as the evidence showed on the high percentage of the ,agree and strongly agree“ responses. However, there were still a varying responses on all statements indicating there was still lack of knowledge on how to include critical thinking components on their instructions. [11] claims that the roles of critical thinking in students can enhance academic achievements. [12] claim that to develop critical thinking skill in learning activity can be regarded as a common issue of education. By giving the current issues, it helps the pre-service student teachers to think creative and critical in developing their ability in learning [13]. Therefore, further study is needed to be done to investigate the pre-service student teachers' knowledge and their skills to implement critical thinking instructions.

\section{CONCLUSIONS}

After analyzing the data on the questionnaire which was fulfilled by 50 respondents, it showed that the perception of the pre-service student teachers toward the critical thinking instruction were still varying. However, the higher one was on the level of agreeing and not extremly high in the strongly agree level. The results indicated that in the teacher training and education program, there is a call for efforts to be done in order to instill the importance of critical thinking for students and the ways to implement it in the instuctions provided by the teachers. It is hoped that the pre-service teachers also need to develop their learning on critical thinking skills so that their level of understanding on critical thinking can be improved. Further study is suggested to be undertaken for exploring more information regarding pre-service student teachers understanding of critical thinking and investigating their teaching practices during the program at the schools so that suitable program could be developed and be given for the pre-service student teachers prior to their teaching practice.

\section{ACKNOWLEDGMENT}

The researchers would like to express our gratitude to the pre-service student teachers at STKIP PGRI Sumatera Barat, Indonesia for giving their responses to the online survey. We also thank to "anonymous" reviewers for their so-called insights.

\section{REFERENCES}

[1] Abdullah, A. H. (2017). Mathematics TeachersLevel of Knowledge and Practice on the Implementation of Higher-Order Thinking Skills (HOTS), 8223(1), 3-17. http://doi.org/10.12973/eurasia.2017.00601a.

[2] Carlson, J. F., \& Geisinger, K. F. (2012). Test reviewing at the Buros Center for Testing. International Journal of Testing, 12(2), 122-135. 
[3] Choy and Cheah. (2009). Teacher Perceptions of Critical Thinking Among Student and its Influence on Hingher Education. International Journal of Teaching and Learning in Higher Education, 20 (2).

[4] Erdos, M. B. (2011). From Ideology to Eidos: Recovering from State Socialism in Hungary. AUDEM: The International Journal of Higher Education and Democracy, 2(1), 5-22.

[5] Gashan, A. K. (2015). Exploring Saudi Pre-service Teachers ' Knowledge of Critical Thinking Skills and their Teaching Perceptions, 3(1). http://doi.org/10.7575/aiac.ijels.v.3n.1p.26.

[6] Ganaphaty, M (2014) ESL Students' Perceptions of the use of Higher Order Thinking Skills in English Language Writing. Advances in Language and Literary Studies, 5(1). http://dex.doi.org/10.7575/aiac.alls.v.5n.5p.80.

[7] Hapsari, S. (2016). A Descriptive Study of the Critical Thinking Skills of Social Science at Junior High School, 10, 228-234.

[8] Lai, E. R. (2011). Critical Thinking: A Literature Review Research Report, (June).

[9] Lucas, K. J. (2019). Chinese Graduate Student Understandings and Struggles with Critical Thinking: A Narrative-Case Study. International Journal for the Scholarship of Teaching and Learning, 13(1), 5.

[10] Livingston, G (2016). The Role of Story in Enhancing Critical Thinking and Group Discussion Skills. The IUP Journal of Soft Skills, X(1).

[11] Masduqi, H. (2006). Critical Thinking Skills And Meaning In English Language Teaching, 185-200.

[12] Santika, A. R., Purwianingsih, W., \& Nuraeni, E. (2018, May). Analysis of students critical thinking skills in socio-scientific issues of biodiversity subject. In Journal of Physics: Conference Series (Vol. 1013, No. 1, p. 012004). IOP Publishing.

[13] K. Saddhono and M. Rohmadi, "A Sociolinguistics Study on the Use of the Javanese Language in the Learning Process in Primary Schools in Surakarta, Central Java, Indonesia." Int. Edu. Stu., vol. 7 no.6 pp 25-30, 2014

[14] Setyarini S, at all. (2018). Thinking Critically While Storytelling: Improving Children's HOTS and English Oral Competence. Indonesian Journal of Applied Linguistict UPI, $8(1)$.

[15] Stedman, N. L., \& Adams, B. L. (2012). Identifying Faculty's Knowledge of Critical Thinking Concepts and Perceptions of Critical Thinking Instruction in Higher Education1. Nacta Journal, 56(2), 9.

[16] Zhang, L., \& Kim, S. (2018). Critical Thinking Cultivation in Chinese College English Classes. English Language Teaching, 11(8), 1-6 